\title{
On the Encounter of Satan and Christ in John Milton's Paradise Lost
}

\author{
SHEN Hong \\ Zhejiang University, Hangzhou, China
}

\begin{abstract}
In Milton's Paradise Lost, Satan is conspicuously depicted as the "mighty chief" (I 566) and "the dread commander” (I 589) of the rebel army. True to the Hebrew meaning of his name, Satan poses appropriately as a grand “Adversary” (I 629; II 282) to “wage by force or guile eternal war” (I 121) against God. The poet has deliberately built up a parallel between Satan and Christ the Son, who is the commander-in-chief of the angelic army. With “Almighty arms / Gird on, and Sword upon [his] puissant Thigh” (VI 713-14), the Son certainly makes an impressive figure of warrior-general. Satan's stance as the "idol of majesty divine” is really extraordinary. During the War in Heaven, he does show superhuman courage and strength; his ability to change his bodily form has no doubt increased his potential as a warrior. Furthermore, he commands a highly disciplined army, surpassing by far the best troops in human history. All this seems to indicate Satan as a great hero. Even before God proclaims the Son to be raised "by merit" to the position of "second omnipotence" (III 309), Milton has already made it clear to the reader that Satan, too, is "by merit rais'd / To that bad eminence” (II 5-6). This ambivalent merit of Satan has incurred heated controversy among the critics. The present paper will set out to analyze the encounter between Satan and the Son in Paradise Lost, in an effort to determine the true meaning of heroism.
\end{abstract}

Keywords: Satan, Christ, John Milton, Paradise Lost, heroism, pagan warrior, Christian virtues, literary tradition

\section{Introduction}

In John Milton's Paradise Lost, there is one paradoxical quality of Satan-his martial spirit. For in the first half of Milton's epic, Satan is consciously depicted as the "mighty Chief" (I 566) and "the dread commander" (I 589) of the rebel army. True to the Hebrew meaning of his name, Satan poses appropriately as a grand "Adversary" (II 629) to "wage by force or guile eternal War" (I 121) against God. Much of the imagery concerning Satan and his followers in these passages is drawn from a military context. In Books I and II, Satan reassembles his shattered followers into a mighty army; while in Books V and VI, the actual war in heaven is depicted in minute details.

The poet has deliberately built up a parallel between Satan and Christ the Son, who is the commander-in-chief of the angelic army. With "Almighty Arms / Gird on, and Sword upon [his] puissant

\footnotetext{
SHEN Hong is a professor of English at Zhejiang University, China. His research is in English literature, Sino-Western cultural relations and exchanges, and missionary studies. He earned his degrees from Peking University, and has been a visiting scholar at the University of Oxford, Harvard University, University of Toronto, University of Bristol. He has published thirty-five books and more than one hundred articles, including “A Century of Milton Studies in China: Review and Prospect” (Milton Quarterly, 48(2), 2014, 96-109), as well as the following books: Milton's Satan and the English Literary Tradition (2010); Diversified Images of the West Lake (2010); Memories of A Heavenly City with Roy Sewall (2010); and China's History Found in the West: The China Reports in The Illustrated London News (7 vols., 2014-2016).
} 
Thigh" (VI 713-14), the Son certainly makes an impressive figure of warrior-general whose gorgeous appearance upon the battlefield is illustrated in the following lines:

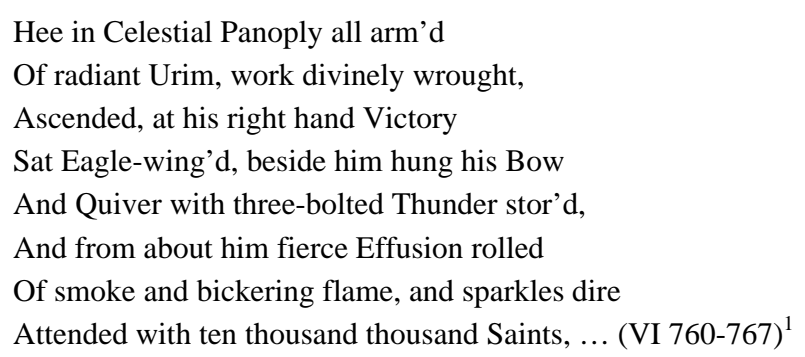

This marvelous scene of the Son's martial display is juxtaposed with an earlier passage depicting Satan, whose coming is no less dramatic and resplendent:

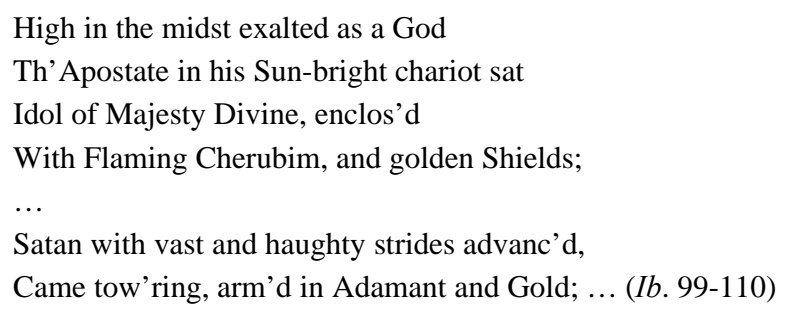

Satan's stance as the "Idol of Majesty Divine" is really extraordinary. During the subsequent fight, he does show superhuman courage and strength; his ability to change his bodily form has no doubt increased his potential as a warrior. Furthermore, he commands a highly disciplined army, surpassing by far the best troops in human history. All this seems to indicate Satan as a great hero. Even before God proclaims the Son to be raised "By Merit" to the position of "Anointed universal King” (III 309, 317), Milton has already made it clear to the reader that Satan, too, is "by merit rais'd / To that bad eminence" (II 5-6).

\section{Is Satan Really a Hero?}

This ambivalent merit of Satan has incurred heated controversy among the critics. The radical Satanists, of course, seize every chance to applaud the rebel leader as a true revolutionary hero who dares to defy the "tyranny" of God; even the more conservative Christian critics, like A. S. P. Woodhouse, feel constrained to acknowledge Satan as an "epic hero". Nevertheless, Woodhouse tries to draw a distinction between the so-called "pagan heroism" and the Christian one ${ }^{2}$. Yet again, by the term "pagan" he refers exclusively to the classical epics of Homer and Virgil, whereas the deep-rooted and permeating influence of the native English literary tradition in Paradise Lost is totally ignored.

This general ignorance has given rise to misunderstandings. It is often believed that the "unconquerable Will” (I 106) of Satan and his rebel angels has something to do with the spirit of the Puritan revolutionaries. A special study on this subject still holds the notion that the military behavior of the rebel angels is by all

\footnotetext{
${ }^{1}$ All quotations in this paper are taken from the text edited by Merritt Y. Hughes in John Milton: Complete Poems and Major Prose, New York: Macmillan Publishing Company, 1985.

${ }^{2}$ Cf. A. S. P. Woodhouse, The Heavenly Muse: A Preface to Milton, University of Toronto Press, 1972, p. 209: "Pagan heroism is heroism built on the basis of pride, of a sense of personal honor, of egoism. Christian heroism is built on the service of God. Let us be quite clear that Satan is heroic, but with a pagan heroism: he has courage, daring, fortitude, and prowess; though even these he loses at last."
} 
standards exemplary and it might well be applied to Oliver Cromwell and his New Model Army (Freeman, 1980, pp. 208-209). However, this literal interpretation is precarious, for it can mislead us into a labyrinth of unsolvable guesswork. In Milton's epic, there are many contradictory details which can apply equally well to the opposite. For instance, Christopher Hill discovers in Paradise Lost some analogies between Satan and the beheaded king, Charles I: they both raise their standards in the north; they are both supported by a third of the total number of the MPs/angels; and the first two days of war in heaven parallel the period of 1642 to 1644 , while the third day equals the period of 1644-1645 (371-372). These speculations, like those of Freeman, are too insubstantial and far-fetched. Freeman is only half-right in assuming that "Paradise Lost interweaves two traditions, one that praises warriors and a second that castigates the devils” (1980, p. 220); but he is entirely wrong in asserting that Milton's treatment of the rebel angels as "warriors" is "innovative" (Freeman, 1980, p. 69), and there was "no significant predecessor" (Freeman, 1980, p. 63).

To illustrate this point, let us turn to the text of Paradise Lost once again. Satan appears in the poem as a giant warrior fully armed, with

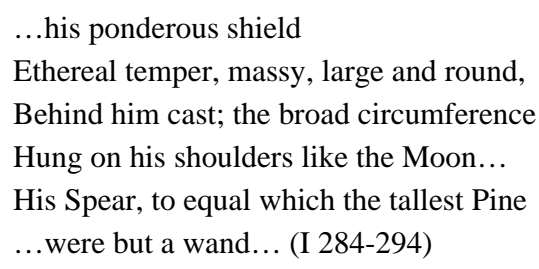

"With this shield," comments J. B. Broadbent in Some Grave Subjects: An Essay on Paradise Lost, "Satan outdoes Goliath and Achilles as epic hero" (1960, p. 73). Yet we should avoid jumping to hasty conclusions, for it is not always the hero who has a giant figure and possesses enormous or splendid weapons. Just think of Orgoglio's “mortall mace” which Spenser refers to as “a snaggy oak” (Faerie Queene I vii 10) and Milton’s own condemnation of the Biblical "men of renown" (Genesis 6:4)— “Giants of mighty Bone, and bold emprise" (Paradise Lost XI 642). A comparison between Milton's Satan with Spenser's Sans brothers might help us clarify this point. The following lines are a description of Sansfoy, a fierce pagan warrior:

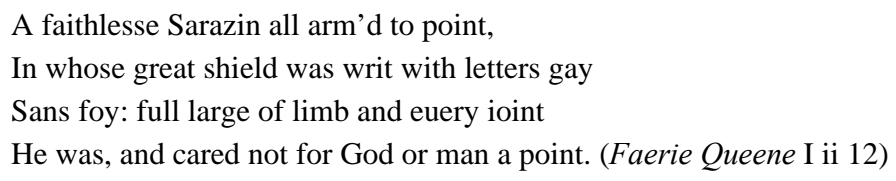

Like his brother, Sansloy is also "Full strongly armed, and on a courser free"- "His look was stern, and seemed still to threat/ Creul reuenge..." (I iii 30). And the last of the three, Sansjoy, maintains an equally ferocious image:

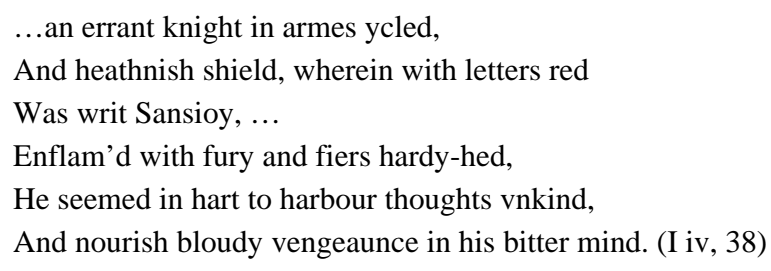

As we can see from Spenser's poem, all three Sans brothers are giants "arm'd to point”, with great shields, mighty spears, and huge swords, the kind of "glorious arms" Harapha would boast of in Milton's Samson 
Agonistes (1130) ${ }^{3}$. It is significant that Spenser consistently addresses each of the Sans brothers as "paynim”4, because Milton uses the same word to illustrate Satan and his followers as "the best of paynim "chivalry / To mortal combat or career with lance” (Paradise Lost I 765-766). In Paradise Regained, Satan again puts on a gorgeous martial parade, and Milton chooses the same word to allude to

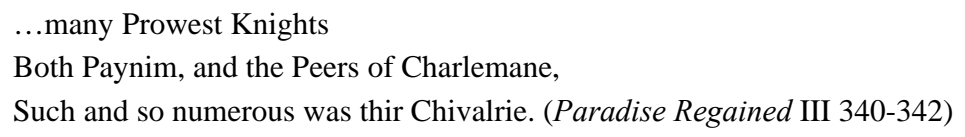

Here we are confronted with one serious question: Can these "paynims"- the "Prowest Knights"-be Milton's or Spenser's heroes? The answer, in my opinion, is definitely negative. Despite their "fierce" countenance and amazing martial skills, the Sans brothers in the Faerie Queene fall far below the Renaissance criterion of heroism, which consists in an excess of virtue, in opposition to an excess of vice. Their superior strength and "glorious arms" are utterly undermined by their wickedness and moral depravity. Consequently,

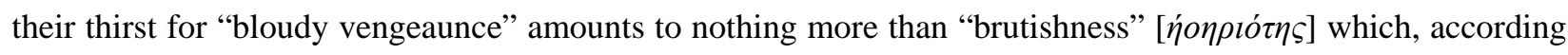
to Aristotle, is characteristic of evil and serves as a foil to heroic virtue (Steadman 24-25). The Sans brothers are allegorical characters of evil and wickedness, and it is by no means a coincidence that their names ("Faithless", "Lawless", and "Joyless") mirror the intrinsic nature of Milton's Satan. As we can often see in Paradise Lost, Satan's malice and atrocity are often hidden behind the facade of grandeur and "chivalry". The same is true of the rest of his rebel army. The exalted style Milton adopted in the epic catalog introducing Satan's twelve generals is undercut by a group of deliberately chosen and pejorative epithets. A choice of these sinister terms helps us to reconstruct a picture of those savage pagan warriors:

Moloch, "the Ammonite” (I 396), is a "horrid King besmear'dwith blood / Of human sacrifice” (I 392-3); Chemos, “th'obscene dread of Moab’s Sons” (I 406) is both "wanton” (414) and "lustful” (415) and is clearly associated with”scandal” (416),"homicide” (417), “lust hard by hate”(417) and”hell” (418); Baalim and Ashtaroth are sexless and shapeless spirits "Like Cumbrous flesh; but in what shape they choose / Dilated orcondensed, bright or obscure" (428-29); Astoreth (or Astarte) is only a "fair Idolatress" (445); Thammuz "allured” (447) and "infected” (453) the Syriandamsels with "wanton passions” (454) and "the darkidolatries / Of alienated Judah” (456-7); Dagon, the "Sea Monster” (462) with “his brute Image” (459), both “sham'd his Worshipers” and is “dreaded” (464); Rimmon, “a leper” (471), burns "his odious offerings" in a "Syrian Mode" (474); Osiris, Isis, and Orus, the next three generals all have "monstrous shapes and sorceries" (479) and are "fanatic" (480) and "brutish" (481); Belial, the most "lewd" (490) and "gross" of them all, is often associated with "vice” (492), "with lust and Violence” (496), "riot” (499), "injury and outrage” (500), "insolence and wine" (502) and "worse rape” (505) 5

It is extremely doubtful that such a rabble of monstrosities can be Milton's real heroes in Paradise Lost. The portraiture of these twelve generals only confirms a negative definition of the word "paynim" in the $O E D$ : when used as a noun or adjective, the term refers to "pagan, heathen", especially to "Mohammedan and Saracen". That is exactly why Spenser refers to Sansfoy as "a faithlesse Sarazin", and why Milton makes a point of telling us that these twelve generals would later turn into heathen idols (Paradise Lost I 367-375).

\footnotetext{
${ }^{3}$ From a TV program, "The Triumph of the West” (Part IV of John Robert's view of world history, on BBC II, 6:30 pm, 12th February 1989), the author of this paper was surprised to witness the enormous shapes of broad swords used by the Ottoman Turkish army in the Middle Ages.

4 "Paynim" is one of Spenser's favorite words. He has used it more than 25 times in the Faerie Queene.

${ }^{5}$ In line with the implication of oriental despotism, Satan, the supreme commander, is repeatedly called the "Emperor with pomp Supreme” (Paradise Lost II 510), “great Sultan” (I 348), “Tyrant” (IV 394), and “Monarch” (II 467).
} 


\section{Satan's Image as a Pagan Warrior}

By representing Satan and his followers as pagan warriors, Milton has surely invoked a deep-rooted tradition in English literature. One of his predecessors, Phineas Fletcher, explores this motif in more explicit terms. Describing the infernal coronation in the Locusts or Apollyonists (1627), Fletcher directly compares the devils to the pagan warriors from the North, the Vikings:

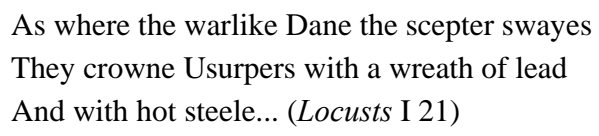

Yet by far a more favorable analogy is to the Ottoman Turks. In Canto III of the same poem, the poet again links up the Devil with the idea of "paynim":

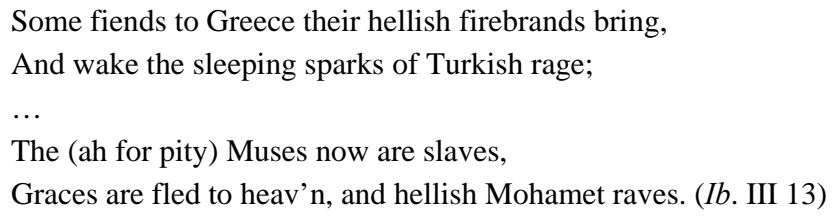

It is quite common for the Renaissance poets to associate Satan with the "hellish Mohamet", who was regarded as a false prophet as well as a symbol of alien power ${ }^{6}$. In Fletcher's long epic contemporary historical events are freely alluded to:

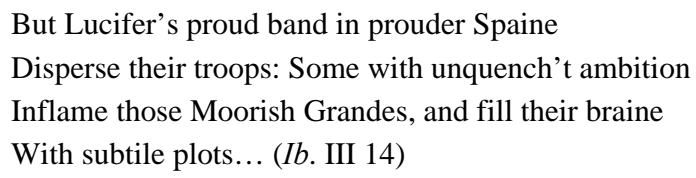

Milton almost certainly took his model of Sin from Phineas Fletcher's poem ${ }^{7}$, and obviously the implications of "paynim" as well. This does not mean, however, that Fletcher or Spenser originated such a literary convention. In William Langland's Piers Plowman, Satan already appears as "one of God's knights" ("on of goddes knyghtes", C text, II 108), who jousts against Christ in Hierusalem by the deputy of a pagan knight, Longinus (C, XXII). An Old English religious poem, Andreas, repeatedly refers to the Devil's pagan followers as "hero” (“hæleð”, 50), "warrior” (“duguð”, 1270), and "thanes” (“begnas”, 43). In the OE Genesis $B$, another possible source of Milton's Satan, the poet thus describes the Devil's deputy ${ }^{8}$ preparing to set off for the temptation of man:

\footnotetext{
${ }^{6}$ The recent Salman Rushdie incident is only a far cry of this deep-rooted Western prejudice which started in the Middle Ages.

${ }^{7}$ Phineas Fletcher, The Locusts, I 10-11:

The Porter to th'infernall gate is Sin,

A shapelesse shape, a foule deformed thing...

Of that first woman, and th'old serpent bred,

By lust and custom nurst, ...

Also cf. Edmund Spenser, The Faerie Queene, I i 14:

Halfe like a serpent horribly displaide,

But th'other halfe did womans shape retaine,

Most lothsom, filthie, foule, and full of vile disdaine.

${ }^{8}$ In this OE poem, Satan is fastened to the bottom of Hell by mighty chains.
} 


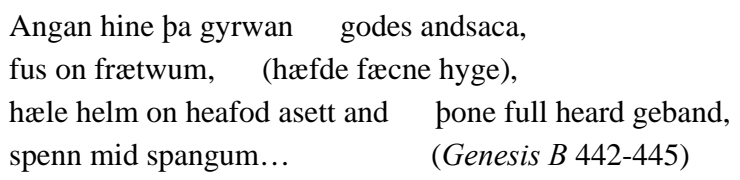

[Then God's enemy began to arm, to put on his war gear. He had a wily heart. He placed on his head the helmet of darkness, fastened the buckles, and bound it firm.]

With all these literary predecessors in perspective, it is not at all surprising that Satan should appear in Paradise Lost as a warrior figure.

Although it could be argued that the martial treatment of Christian themes belongs to the biblical or Latin conventions, the concept of Satan and his rebel angels as pagan warriors is in fact rather a unique phenomenon in English literature. None of the Hebrew or the Continental authors before Milton had given any similar depictions of Satan as a pagan warrior-general ${ }^{9}$, whereas in English literature the Arch-devil's martial image recurs so frequently that it has almost been taken for granted.

To understand this uniqueness, we need to trace the myth back to its biblical sources. The war in heaven is only faintly alluded to in the Bible: "Isaiah" introduces Lucifer as "King of Babylonia, bright morning star" that has "fallen from heaven" (14: 12); "Ephesians" employs the metaphor of God's armor: "Put on all the armour that God gives you, so that you will be able to stand up against the Devil's evil tricks" (6: 11); Christ claims in "Matthew" that he brings not peace, but a sword; and it is "Revelation" that actually sketches the outline of this skirmish the good and bad angels:

The war broke out in heaven. Michael and his angels fought against the dragon, who fought back with his angels; but the dragon was defeated, and he and his angels were not allowed to stay in Heaven any longer. The huge dragon was thrown out - that ancient serpent, called the Devil, or Satan, that deceived the whole world. He was thrown down to earth, andall his angels with him. (12: 7-9)

Yet from these accounts, we find no description of a concrete warfare, and Satan is still in his primeval form of a dragon.

In the fourth century, a Christian poet, Prudentius, wrote a Latin poem called The Psychomachia. It is an allegory about the conflict of good and evil, depicted in the fashion of the holy war. His vivid account of hand-to-hand combats between personified Virtues and their counterpart Vices has indeed had great influence on the medieval European dramas and allegorical poems. Nevertheless, since abstract nouns in Latin take the feminine gender, all the characters of Virtues and Vices represented by Prudentius are female; and these Amazon warriors are not really compatible with the image of giant "paynim” warriors in Milton's epic.

In Old English religious poems, however, the biblical myth is adapted in a unique manner to fit into the mode of Germanic heroic poetry. The result is a hybrid version of full-scale warfare between two enemy tribes, in which the devils are made to put on armor as pagan warriors. The principal idea behind this literary accommodation is related to the typically antagonistic Anglo-Saxon wisdom:

$$
\begin{aligned}
& \text { God sceal wið yfele... } \\
& \text {...leaht sceal wiðpystrum, }
\end{aligned}
$$

\footnotetext{
${ }^{9}$ Professor Taylor, who has traced many parallel descriptions between Milton and Du Bartas, has to admit: "The magnificent Satan of Books I and II of Paradise Lost shows no signs of the influence of Du Bartas” (G.C. Taylor, Milton's Use of Du Bartas, Harvard University Press, 1934, p. 72); and “there appear to be no borrowings from Du Bartas in Book VI [the war in heaven]” (ib. p. 85).
} 
fyrd wið fyrde, feond wið oðrum,

lað wið lape ymb land sacan,

synne stælan. (“Maxims” II 50-54)

[Good must be against evil ... light against darkness, army against army, one enemy against another, foemust fight against foe for land, pursuing violence. $]^{10}$

Therefore we see the holy war retold in the OE Guthlac A, where the deadly horde of devils fight against the angelic army sent by God to protect Guthlac, who is himself "a soldier of Christ" ("Cristes cempa”, 262). There is a flourishing of weapons, a "clamour of many sorts" and a "loud war-cry" ("Ba wearð breahtm hæfen ... wið up astag...”, 592-593). In Andreas, the apostles of Jesus are significantly called "twelve ... renowned warriors / Lord's thanes” (“twelfe under tunglum tireadige hæleð, / peodnes pegnas”, 2-3), while Christ himself becomes the "high king of heaven" ("heofona heahcyning”, 6). The Mermedonians, "the thanes of the Devil” (“deofles pegnas", 43), on the other hand, are held to be "a nation of warriors" ("hæleða eðel”, 21), the "fierce enemy" ("hettend heorogrimme”, 31), or the "blood-greedy warrior" ("manfulra hloð”, 42). The struggle between Christ and the Devil is therefore considered as a regular war between two antagonistic tribes - one Christian, the other, heretic. Weapons of all kinds are listed throughout the poem, including "shield", "sword”, "spear”, "broad sword”, etc. As a result, the biblical myth is heavily modified by the heroic convention of Anglo-Saxon poetry.

In the OE Genesis, the defection of the rebel angels is discreetly subjected to the censure of the Anglo-Saxon ethical code. In the following passage, Christ is presented as a great warlord of the comitatus, with his band of thanes united in loyalty around him, so as to obtain his protection and bounty. However, this loyalty has been ruptured by one of his archangels:

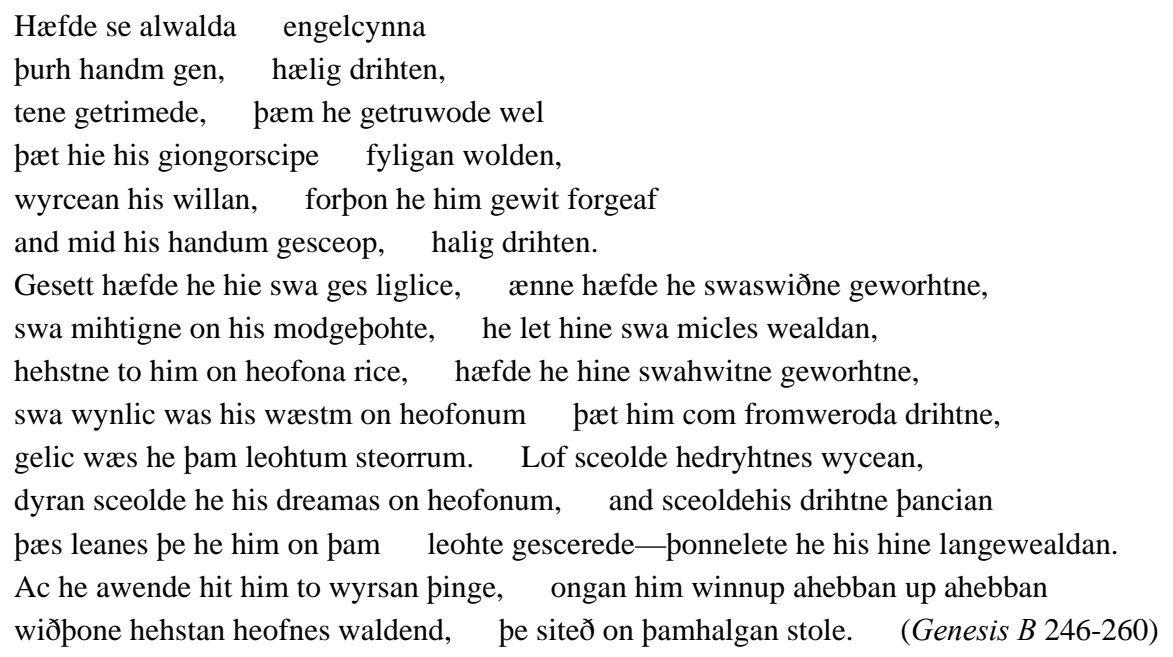

[The Ruler of all, the holy Lord, by the might of his hand had ordained ten orders of angels in whom he firmly trusted that they would follow in his fealty and work his will since he, the holy Lord, had given them intelligence and shaped them with his hands. So blessedly had he established them, and a certain one he had

\footnotetext{
10 These still remained to be Renaissance English poets' favorite themes. In Paradise Lost, we see the basic moral pattern of good against evil, the striking imagery of light against darkness, and we still read such maxims as "army against army" (Paradise Lost, VI 224). When describing the fierce combat between Sansloy and Redcrosse, Spenser emphatically reiterates the line: “So th' one for wrong, the other strives for right" (Faerie Queene, I V 8, 9).
} 
made so strong and so powerful in his intellect, so much had he allowed him to command, the highest after himself in the realm of the heavens, so dazzling had he made him, so winsome was his person in the heavens which came to him from the Lord of the angel multitudes - he was comparable to the incandescent stars - he ought to have done homage to the Lord, he ought to have thanked his Lord for the bounty he has allotted him in that existence: then he would let him rule it in perpetuity. But he turned it to his own worse purpose: he began to stir up trouble against the supreme Ruler of heaven who sits upon the holy throne.]

Satan is clearly portrayed as a treacherous vassal who turns shamelessly against his own lord. In so doing he violates the established moral values in Anglo-Saxon society, abandons his prime obligation, thus making himself a target of stigma for the readers.

\section{Milton's Literary Accommodation of a Native Tradition}

Such an association of Christian theology with the ideas of a Germanic military society is natural to the newly converted Anglo-Saxons. Since the conversion of faith is such a delicate matter, it is unrealistic to expect people change their way of thinking overnight. The early Christian mission took a tactful approach towards this problem; they did not try to destroy the old pagan tradition and customs right away, and replace them with the orthodox Christian system and services. Instead, they tended to instill new meanings into the old concepts to make them serve Christian purposes. A well-known example is Pope Gregory’s letter to the Abbot Mellitus, who was on his way to Britain, urging him to convert the temples of the idols from the worship of the devils to the service of God. ${ }^{11}$

The effects of this moderate policy are both far-reaching and profound, and the same treatment of these “well-built” pagan temples by sprinkling "holy water" and placing "altars" and sacred "relics" has been metaphorically applied to Old English poetry as well. Take Beowulf for example: in this typically Germanic epic, scraps of the Genesis story are strewn into its narrative frame to make them part of a fabulous story. The monster, Grendel, is ascribed to the family of Cain:

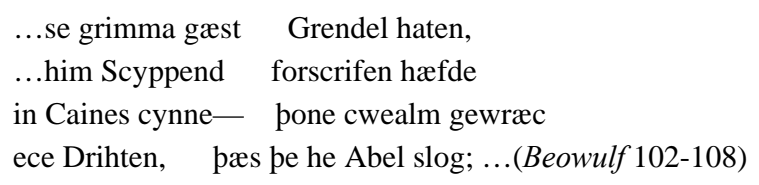

[...the savage visitor was called Grendel... the Creator had proscribed him along with the stock of Cain. The everlasting Lord avenged the murderous act because he slew Abel.]

When Beowulf is struggling under the "grim clutches" ("grimman grapum”, 1542) of Grendel’s mother, he nearly loses hope. It is God (“the holy God”, 1553, “wise Lord”, 1554, “arbiter of the heavens”, 1555) who comes to his succor at this critical moment to set him free, and to show him that "ancient, gigantic sword" (1558) on the wall, with which he slays the she-monster. The language conveys unmistakable Christian implications. Again, as Beowulf shows the richly-decorated hilt of the magic sword to Hrothgar, the poet

\footnotetext{
${ }^{11}$ Cf: Bede, The Ecclesiastical History of the English Nation, Book I, Chapter 30:

...the temples of the idols in that nation ought not to be destroyed; but let the idols that are in them be destroyed; let holy water be made and sprinkled in the said temples, let altars be erected and relics placed. For if those temples are well built, it is requisite that they be converted from the worship of devils to the service of the true God; that the nation, seeing that their temples are not destroyed, may remove error from their hearts, and knowing and adoring the true God, may they more familiarly resort to the places to which they have been accustomed.
} 
deliberately tells us that the story of the biblical giants and their destruction is engraved on it. ${ }^{12}$

It is especially interesting that the figure of Grendel throws some light upon the Anglo-Saxon idea about the Devil. As we have already seen, this diabolical character is ascribed to the demon offspring of Cain, and throughout the long epic, the poet applies to him various terms commonly used for the Devil in OE literature. He is repeatedly called a "death-shadow” (“deað- scua”, 160), "evil spirit” (“werga gast”, 1747), "terrible monster” (“atol æglæca”, 592), “enemy in hell” (“feond on helle”, 101), "hell-demon” (“helle-gast”, 1274) and, like Satan, he is "God’s adversary" ("godes andsaca”, 786; 1682). Grendel not only perpetuates affliction and violence against humankind, but indeed "he is antagonistic towards God” ("he [wæs] fag wið God”, 811). More significantly, as the "enemy of mankind" ("feond mancynnes", 164; 1276), this monster is also sometimes treated as man, a Germanic warrior- "the unblest man" ("wonsæli wer”, 105), "the cruel-hearted warrior" ("gromheort guma”, 1682). In terms of martial skill, he is certainly "illustrious" ("se mæra”, 762), and his fierceness in physical combat is notorious. For twelve years, he has inflicted terror to the country of Denmark, and there was not a single opponent:

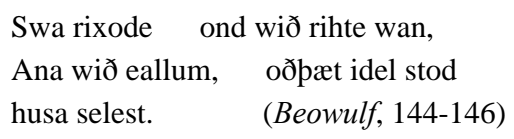

[So he prevailed, in defiance of right, he contended with them, one against all, until that finest of halls stood useless.]

The poet further tells us that he carries on ceaseless strife, refusing to negotiate wergild with the Danes. ${ }^{13}$ This colorful piece of detail provides us with a good example of the English literary tradition to which Milton is indebted.

The influences of two different cultures are often reciprocal. On the one hand, many Christian elements have been absorbed into the pagan frame of Anglo-Saxon poetry; on the other hand, some originally pagan concepts become Christianized. "Wyrd", the Anglo-Saxon concept of unpredictable fate which ultimately determines human life, is reinterpreted in the $\mathrm{OE}$ version of Boethius' The Consolation of Philosophy as being under the control of the omnipotent and omniscient God. "Lof", the other popular heroic motif which originally only referred to the secular fame won by overcoming human enemies, now becomes a spiritual reputation attained through good deeds and bravery against the Devil. "The Seafarer" thus defines this heroic term:

\footnotetext{
12 Cf. Beowulf, 1688-1693:

...ealde lafe, on ðæm wæs or writen

fyrngewinnes, syðpan flod ofsloh,

gifen geotende giganta cyn,

frecne geferdon; pæt wæs fremde peod

ecean Dryhtne; him pæs endelean

purh w teres wylm Waldend sealde.

[On it was engraved the beginning of the age-old war; subsequently, the Flood, an overwhelming deluge, killed the race of giants--they had behaved wickedly. It was a people alienated from the eternal Lord; because of this the Ruler gave them final payment in the rising of the water.]

${ }^{13}$ Cf. Beowulf, 154-156:

sibbe ne wolde

wið manna hwone mægenes Deniga,

feorhbealo feorran, fea pingian.

"Wergild" is an old Germanic custom of paying a sum of money to the enemy tribe, in order to settle a feud.
} 


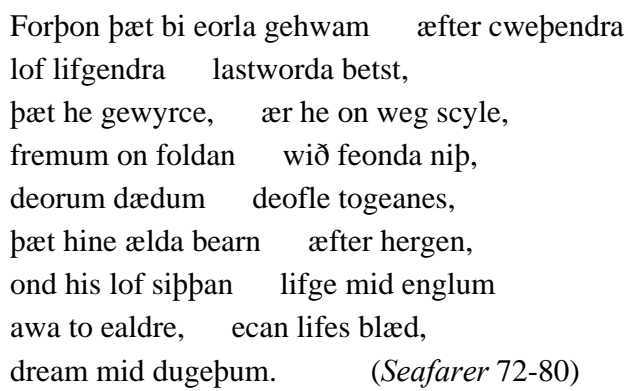

[For every man, therefore, fame of the living, speaking out afterwards, is the best of epitaphs: that, before he has to be on his way, he accomplishes gains against the malice of fiends, brave deeds in the devil's despite, so that the sons of men may afterwards extol him, and his fame may endure for ever and ever among the angels, and the splendor of his eternal life and his pleasure endure among the celestial host. $]^{14}$

The OE Andreas and Guthlac belong to a literary genre known as saints' lives, from which we can see another interesting change in Anglo-Saxon society. After Christianity was introduced into Britain in 597, monasticism was established among the Anglo-Saxons as a socially acceptable mode of life. Among the prominent churchmen of that time, many had served previously in the war-bands of their kings. The Mercian hermit St. Guthlac is just such an example. Legends are told how, upon serious contemplation, he is abruptly determined to abandon his military career in favor of a hermit life in the wilderness. ${ }^{15}$ Benedict Bishop, another famous religious figure and the founder of the twin monasteries of Monk wear mouth and Jarrow, had also served as a thane to King Oswin of Northumbria before he entered religion at the age of twenty-five. ${ }^{16}$ Once the lives of such saints are made into poems, it is not surprising that the matter of hagiography should be thronged with the heroic theme and imagery. Both Andreas and Guthlac, indeed, deal with the spiritual combat, yet the protagonists are presented in such heroic or martial terms that the reader often tends to appreciate them in the light of a secular hero. As we have already mentioned, St. Andrew is hailed as one of the "twelve renowned warriors.../ Lord's thanes” (2-3). In his sea-journey to Mermedonia to rescue St Matthew from the cannibals, he is further portrayed as a Beowulf-like hero, setting out to help another Hrothgar-only this time he is carrying out the mission of God. The vocabulary of Anglo-Saxon heroic ethics reaches a new height when his followers refuse to leave him alone in the dangerous ship:

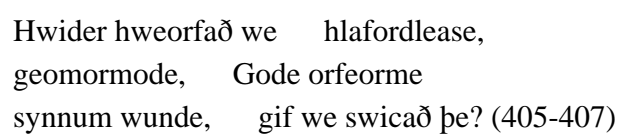

[Where shall we turn—lordless, melancholy, lost to all good, stricken with sins—if we desert you? ${ }^{17}$

\footnotetext{
14 J. M. Evans has discussed this important issue in his book Paradise Lost and the Genesis Tradition (Oxford: The Clarendon Press, 1968). He points out: "When the vocabulary of such a society [Anglo-Saxon society] was superimposed on the Christian world-picture, two things happened: first, the vocabulary itself was modified and words like 'dom', 'lof', and 'wyrd' came to acquire a new resonance; second, the more subtle and spiritual aspects of the church's teaching were coarsened by the heroic emphasis on physical valor and material reward and punishment” (p. 144).

15 Cf. Michael Swanton, English Literature before Chaucer, Longman, 1987, p. 142 f: Guthlac's life is recorded by his eighth-century biographer Felix in the Life of Saint Guthlac, B. Colgrave (Ed.), Cambridge, 1956. Born about AD 673 into a branch of the Mercian royal house, he became the leader of an independent comitatus during a particularly turbulent period for this warlike frontier province. At the age of 24 , he entered the monastery at Repton. Two years later, he withdrew into the wilderness, establishing a hermitage at Crowland, where after 15 years of singular austerity he died in 714 .

${ }_{16}$ Dorothy Whitelock, The Beginnings of English Society, London: Penguin Books, 1987, p. 36.

17 One of the most important values in Anglo-Saxon society is the concept of "comitatus". To be "lordless" is the worst plight possible.
} 
Nevertheless, "the battle-hardened warrior", St. Andrew, is destined not to fight literally, but to pray, to exercise his patience and suffer the cruel atrocity of the Mermedonians ${ }^{18}$ in a dignified manner, just as the young warrior, Jesus Christ, does in The Dream of the Rood.

With his mighty sword, Guthlac is no less a heroic figure, but we are clearly told that he, too, is applying passive contemplation. Being a miles spiriti, he remains as "a warrior, fighting for God in his heart" "swa sceal orette a in his mode / gode campian”, 344-345). The heroic pattern here is distinctively different from the one in either classical epic or medieval romance. It embraces both the active and passive moods of fortitude, recognizing martial potency while giving primal emphasis to the patience of suffering and obedience to God. This provides a clue to the heroic pattern in Paradise Lost, which is neither a celebration of physical strength nor a pompous display of lethal arms.

In Paradise Lost, the portrayal of Satan is constantly juxtaposed with the characterization of the Son. Thus the Arch-devil's pseudo-heroism provides a point of reference to Christ's heroic fortitude, which certainly serves as the standard pattern of heroism. If we say Satan's power is to destroy, "to find means of evil" out of good, and "To wage by force or guile the eternal War / Irreconcilable" against God and mankind (Paradise Lost I 165, 121-22), then Christ's strength is mainly represented through his work of creation and his offer to redeem the sins of mankind. After the rebel angels' riot has brought disastrous affliction to the kingdom of heaven, God the Father dispatches the Son as his deputy to rebuild the universe:

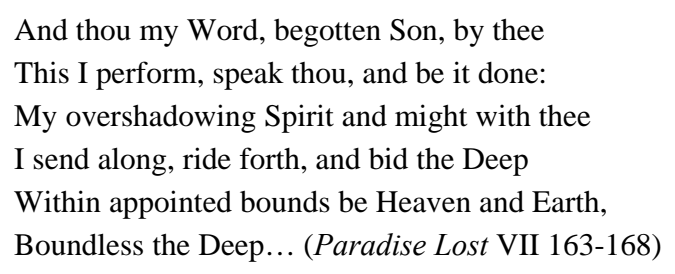

In the subsequent angelic hymn glorifying the divine work of creation, Milton explicitly confirms the superior strength of the Son:

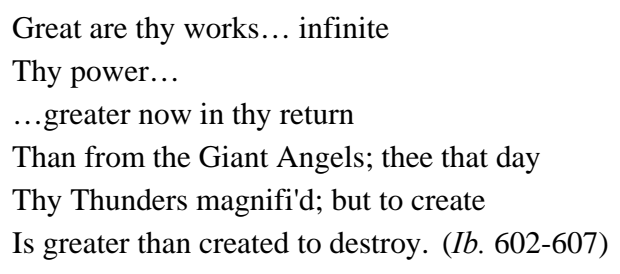

In sheer might of destruction, the fallen angels have indeed surpassed the most famous heroes of epic and romance- - "For never since created man, / Met such imbodied force... / ...Thus far these beyond / Compare of mortal prowess...” (Paradise Lost I 573-588). In comparison, the martial skill of the good angels is at best equal to that of the rebel angels. This is how Milton describes the duel between Satan and the archangel Michael:

Together both with next to Almighty Arm, Uplifted imminent one stroke they aim'd That might determine, and not need repeat, As not of power, at once; nor odds appear'd In might or swift prevention... (Paradise Lost, VI 316-320)

\footnotetext{
${ }^{18}$ St. Andrew is put into a dark dungeon and nearly tortured to death. It is only God's miracle that finally saves his life. Cf. Andreas, 1238-1240: “Wæs pæs halgan lic / sarbennum soden, swate bestemed, / banhus abrocen. Blod yðum weoll, hatan heolfre.”
} 
But Michael has the sword "from the Armory of God" (ib. 321), which enables him to wound the mighty chief of the rebel army.

The "Armory of God" here has a strong biblical connotation of "obedience" and "faith" to God (“Ephesians”, 6: 11), for towards the end of Milton’s long epic, St. Michael predicts to Adam that God will send John the "Comforter" to mankind to ensure "the Faith / Working through love... To guide them in all truth, and also arm / With spiritual Armour, able to resist / Satan's assaults, and quench his fierye darts...” (XII 489-492). The familiar Anglo-Saxon admixture of heroic and hagiographic elements asserts itself distinctively through this image. It is most common in English religious poems that the Christian hero ultimately overcomes his puissant enemy with this divine weapon. The dramatic scene in which Abdiel overthrows the Arch-devil because of his faith is just such an example. Being a "servant of God", Abdiel has strong conviction in the divine power; and before striking his blow at Satan, he makes a fervent prayer to God:

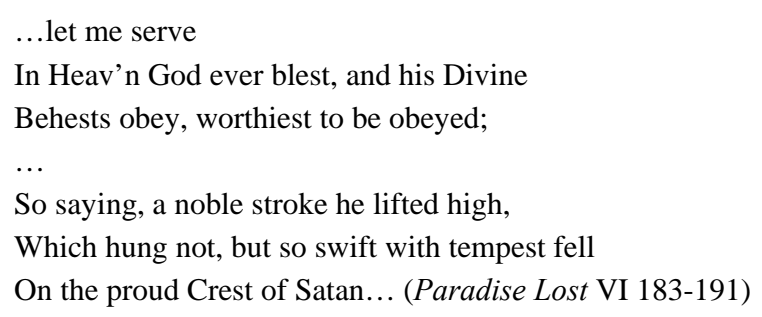

Almost incredibly, the "mighty chief” of the devils' army falls tumbling down to the ground.

A very similar episode occurs in Spenser's Faerie Queene: in Canto I, the Recrosse Knight has nearly been strangled to death by the serpentine monster, Error. At this critical moment, Una reminds him of his Christian faith:

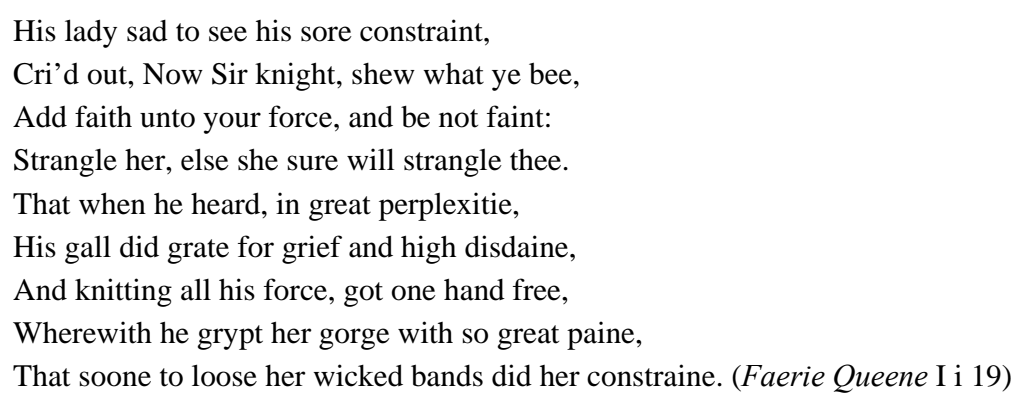

This familiar pattern of "adding faith to the force”, reiterated in Michael's moralizing to Adam ${ }^{19}$, can be traced back to Anglo-Saxon poetry, where the sword with which Beowulf killed Grendel's mother is, on the anagogical scale, also from the “Armory of God”. In another Old English poem, Elene, the Roman emperor is able to rout the savage pagan army by simply holding high the holy cross in front of his own troops. St. Andrew in Andreas is captured and tortured by the Devil's pagan servants, but he wins the final victory through a miracle from God. It is, once again, brought about by his renewed faith and ardent prayers. The thunders Christ carries in hand are the same kind of divine miracle, with which he easily vanquishes Satan's army, and drives them into the abyss of hell.

The holiness of Christ has set the genuine heroic pattern in Paradise Lost. It is both active and passive: 19 Paradise Lost, XII 576-583: "This having learned, thou hast attained the sum / Of wisdom, hope no higher, ...only add / Deeds to
thy knowledge answerable, add faith, / Add virtue, patience, temperance, add love...”. 
active in the sense of being able to heroically overmatch Satan's ostentation of martial power; passive because it stresses the Son's faith and obedience to God. Christ emerges from the war in heaven as the archetype of epic hero- "His count'nance too severe to be beheld / And full of wrath bent on his Enemies" (Paradise Lost VI 825-826). Yet the pre-eminent excellency of Christ's heroism is manifested not in his martial skill, but in the patient trust in the power of God, and in his willingness to endure sufferings. The moral of this "better fortitude /Of Patience and Heroic Martyrdom” (Paradise Lost IX 31-32) is reflected in Adam's speech near the end of the poem:

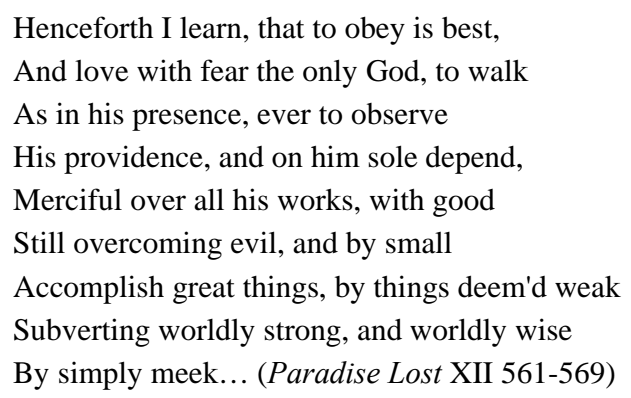

Despite his destructive martial potency, Satan remains in essence impotent. It is God's power that is truly omnipotent. Paradoxically, the moral reality behind Satan's habitual display of might is nothing but frailty. For according to the Christian doctrine, power is really the gift of God, and the creature has no grounds for glorifying his own strength. Gabriel cuts short Satan's vaunt of his own martial power with these remarks: "Satan, I know thy strength, and thou know'st mine, / Neither our own but giv'n; what folly then / to boast what arms can do" (Paradise Lost IV 1006-1008). In the very act of rebelling against God, Satan has actually dissociated his strength from its proper source, thus reducing himself to weakness and infirmity. Raphael is certainly right when he points out:

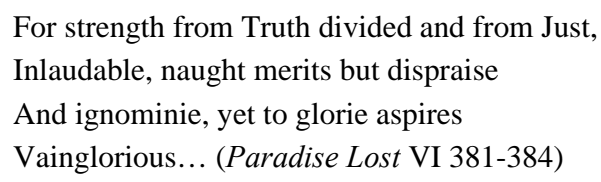

Milton himself in Paradise Regained ridicules Satan's "vain" ostentation of "fleshly arm, and fragile arms” (Paradise Regained III 387).

After examining the heroic theme in Paradise Lost with reference to the English literary tradition, we can now say, with some degree of certainty, that Satan's ponderous shield and mighty spear are not symbols of his heroism, but merely the "cumbersome Luggage of war" which presents an "argument of ...human weakness rather than of strength” (Paradise Regained III 401-402).

\section{Conclusion}

Through the above analysis of Satan's Image as a "the dread commander" (Paradise Lost I 589) of the rebel army and a martial-spirited pagan warrior, we come to realize that in his nature, Satan is not so powerful as he appears to be. His wickedness and moral depravity have prevented him from being a "hero," in the real sense of the word. In depicting Satan as a pagan warrior, Milton is actually appealing to a deep-rooted tradition in English literature, which could be traced back to Old English literature. The real hero of Milton's long epic is Christ, the Son, who in every way forms a contrast to his adversary, Satan. Christ represents the Christian 
virtues of faith, humility and obedience. These virtues have confirmed what Milton claims to be the "higher argument” (Paradise Lost IX 42) of his heroic epic- “the better fortitude / of Patience and Heroic Martyrdom” (Paradise Lost IX 31-32).

\section{References}

Bede. (1954). The ecclesiastical history of the English nation. London: J. M. Dent \& Sons, Ltd. Broadbent, J. B. (1960). Some graver subject: An essay on Paradise Lost. London: Barnes \& Noble. Evans, J. M. (1968). Paradise Lost and the Genesis tradition. Oxford: The Clarendon Press.

Fletcher, R. (Ed.). (1896). The prose works of John Milton. London: Henry G. Bohn.

Freeman, J. A. (1980). Milton and the martial Muse. Princeton: Princeton University Press.

Hill, C. (1979). Milton and the English revolution. London: Penguin Books.

Hughes, M. H. (Ed.). (1985). John Milton: Complete poems and major prose. New York: Macmillan Publishing Company. Smith, J. C., \& De Selincourt, E. (Eds.). (1966). Spenser: Poetical works. London: Oxford University Press.

Steadman, J. M. (1968). Milton's epic characters. Chapel Hill, North Carolina: The University of North Carolina Press. Swanton, M. (1987). English literature before Chaucer. London: Longman.

Taylor, G. C. (1934). Milton's use of Du Bartas. Cambridge, Mass.: Harvard University Press.

Woodhouse, A. S. P. (1972). The heavenly Muse: A preface to Milton. Toronto: University of Toronto Press. 